\title{
The nest and eggs of Black-capped Sparrow Arremon abeillei abeillei (Passerellidae) in southwestern Ecuador
}

\author{
Harold F. Greeney \\ Yanayacu Biological Station \& Center for Creative Studies, km 5, via Las Caucheras, Cosanga, Napo, Ecuador.e-mail: antpittanest@gmail.com \\ Editado por/Edited by: Juan F. Freile \\ Recibido/Received: 26 Febrero 2018. Aceptado/Accepted: 11 Septiembre 2018. \\ Publicado en línea/Published online: 26 de Noviembre 2018.
}

Nido y huevos del Saltón Gorrinegro Arremon abeillei abeillei (Passerellidae) en el suroeste de Ecuador

\begin{abstract}
Resumen
Describo el nido y el huevo del Saltón Gorrinegro Arremon abeillei abeillei, proporcionando la primera información documentada sobre su biología reproductiva y el primer reporte de parasitismo por el Vaquero Brilloso Molothrus bonariensis. Estudié siete nidos en dos lugares en el suroeste de Ecuador. Los nidos son estructuras cerradas, en forma de horno, con una entrada lateral, ocultas entre la hojarasca, tanto en terreno plano como en terreno inclinado. El tamaño de la puesta confirmada en un nido fue de cuatro huevos; 13 huevos observados variaron desde cremoso pálido hasta blanco puro, marcados escasamente con manchas de color marrón oscuro o negro, manchas pequeñas y garabatos cortos. La arquitectura del nido es similar a la de los congéneres tradicionalmente clasificados en los géneros Arremon y Lysurus, incluso a los miembros del género Arremonops, pero no es congruente con los nidos de copa abierta de taxones relacionados históricamente ubicados en los géneros Buarremon o Atlapetes. La coloración del huevo sugiere similares relaciones entre estos géneros.
\end{abstract}

Palabras clave: arquitectura del nido, Arremon abeillei, biología reproductiva, Saltón Gorrinegro, historia natural, huevo, Passerellidae.

\begin{abstract}
I describe the nest and egg of Black-capped Sparrow Arremon abeillei abeillei, providing the first substantiated information on its breeding biology and the first report of brood parasitism by Shiny Cowbird Molothrus bonariensis. I studied seven nests at two locations in southwestern Ecuador. Nests are enclosed, oven-shaped structures with a side entrance, concealed amongst leaf litter on either flat or sloping ground. Confirmed clutch size at one nest was four eggs; 13 eggs observed varied from very pale buff to pure white, sparsely marked with dark brown or black flecks, small spots, and short scrawls. Nest architecture is similar to that of congeners traditionally placed in the genera Arremon and Lysurus, and to members of the genus Arremonops, but differs from the open-cup nests of related taxa historically placed in the genera Buarremon or Atlapetes. Egg coloration reflects similar relationships within these genera.
\end{abstract}

Keywords: Arremon abeillei, Black-capped Sparrow, breeding biology, egg, natural history, nest architecture, Passerellidae.

\section{INTRODUCTION}

There are 48 taxa currently included within the genus Arremon, a morphologically uniform group of robust, generally ground-foraging New World sparrows (Passerellidae) found across most of Central and South America (del Hoyo et al., 2018; Remsen et al., 2018). The breeding biology of Arremon is poorly documented, with fewer than half of these taxa having published nest descriptions. There is a single published description of the nest and eggs of Black-capped Sparrow Arremon abeillei (Armani, 1985). Armani (1985) describes the nest as furnace-shaped, composed externally of leaves and rootlets and lined with fine fibers, placed on the ground amongst the roots of trees or shrubs. He gives clutch size as two eggs, describing them as white, marked with brown and blackish. The basis for this description is not specified; no sample size, date, or location are given. Despite the fact that this description appears to be more or less accurate, other descriptions in Armani (1985) have proven to be unreliable and unsubstantiated by direct observations or verifiable data (K. Zyskowski, in litt. 
2018). It is highly desirable, therefore, to have a well-documented, quantified description of the nest and eggs of this poorly-studied species. Traditionally, A. abeillei is treated as including two subspecies: A. abeillei abeillei and A. a.nigriceps (Dickinson \& Christidis, 2014). The latter is confined to the Upper Marañón Valley of extreme southern Ecuador (southern Zamora-Chinchipe) and northwest Peru (eastern Cajamarca), and is considered by some to merit full species status (Marañón Sparrow A. nigriceps; del Hoyo \& Collar, 2016). Nominate abeillei, similarly range-restricted and also lacking information on its breeding biology, is found from southwestern Ecuador (south from Manabí) to western Peru (south to western Cajamarca). Herein, I provide descriptions of the nest and egg of nominate abeillei, based on seven nests studied in southwest Ecuador.

\section{METHODS}

I studied the nesting of Black-capped Sparrow at two locations in southwestern Ecuador. In February 2006, I made several short visits to Bosque Protector Cerro Blanco $(-2.150168,-80.042765 ; 300 \mathrm{~m}$ a.s.1.), a private reserve located $15 \mathrm{~km}$ west of Guayaquil, Guayas province (see Mischler \& Sheets, 2007; Mischler, 2012). In February and March 2006, 2010, and 2014 I made periodic visits to the Reserva Privada Jorupe (-4.381419, 79.895106; 600 m a.s.1.), near Macará, Loja province (see Miller et al., 2012). Habitat at both reserves is mostly lightly to moderately disturbed tropical deciduous forest, typical of the Tumbesian bioregion (Best \& Clarke, 1991; Best \& Kessler, 1995). The fairly open forest canopy is $15-25 \mathrm{~m}$ above a dense, tangled, rather spiny understory and is dominated by widely-spaced, canopy-emergent Ceiba trichistandra (Bombacaceae) trees. I discovered and studied nests opportunistically, during the course of other field work.

\section{RESULTS}

\section{Nest architecture and placement}

I studied seven nests, six of which were completed and one which I was not able to follow through to clutch initiation. A summary of the dates and locations of all breeding records is presented in Table 1. The nests of Black-capped Sparrow are built on the ground. They are enclosed, fairly messy, oven-shaped, balls of small sticks, dead leaves, rootlets, and plant fibers, entered through an opening in the side (Fig. 1). Materials are generally coarser on the outside, finer on the inside, and the inner portion of the egg cup is lined almost exclusively with fine, flexible fibers (mostly dark colored) that include dark rootlets, long strands of mammalian hair (horse or cow), fungal rhizomorphs (Marasmius sp.), and thin, pale grass stems. Measurements (cm) for six nests are presented in Table 2. Although it was not always easy to see, it appears that all nests also included a "runway" of arranged material extending along the ground in front of the nest, as has been described for other species with similar nests, particularly those of several genera of New World warblers (Parulidae; see Curson, 2010). The materials included in these runways differed little from those used in the outer portions of the nest and from the surrounding leaf litter. These runways were generally slightly narrower than the outer width of the nest, and their obviousness, length, and thickness seemed to vary with the steepness of the slope on which the nest was built; with those on steeper slopes tending to have looser, less obvious runways. Runway length $(\mathrm{cm})$ of the six nests was: $7.5,7, c .11,10,6$, and 10. Three of the seven nests I examined were built on nearly level ground, two were on moderately inclined ground (slope $c .30-45^{\circ}$ ), and two were on small, nearly vertical, banks.

\section{Eggs}

The eggs of Black-capped Sparrow ( $n=13$ ) are very pale buff to pure white with sparse, dark brown to black flecks, small spots, and short scrawls (Fig. 2). A complete clutch of four very fresh eggs at Cerro Blanco on 25 February 2006 had the following measurements: $22.7 \times 17.1 \mathrm{~mm}, 3.59 \mathrm{~g} ; 23.6 \times 16.9 \mathrm{~mm}, 3.69 \mathrm{~g} ; 23.2 \times 16.9$ $\mathrm{mm}, 3.66 \mathrm{~g} ; 23.7 \times 16.5 \mathrm{~mm}, 3.46 \mathrm{~g}$ ). Three undeveloped eggs of a possibly incomplete clutch at Jorupe on 15 February 2010 measured: $22.87 \times 18.01 \mathrm{~mm}, 3.99 \mathrm{~g} ; 23.70 \times 16.98 \mathrm{~mm}, 3.79 \mathrm{~g} ; 23.30 \times 17.10 \mathrm{~mm}, 3.77 \mathrm{~g}$. Three fresh eggs of a possible incomplete clutch at Jorupe on 2 March 2014 measured: $22 \times 17 \mathrm{~mm}, 3.5 \mathrm{~g}$; 24 $\times 17 \mathrm{~mm}, 3.6 \mathrm{~g} ; 23 \times 17 \mathrm{~mm}, 3.5 \mathrm{~g}$. Also at Jorupe, a nest found 1 March 2010 contained three sparrow eggs and one egg of the Shiny Cowbird Molothrus bonariensis. 


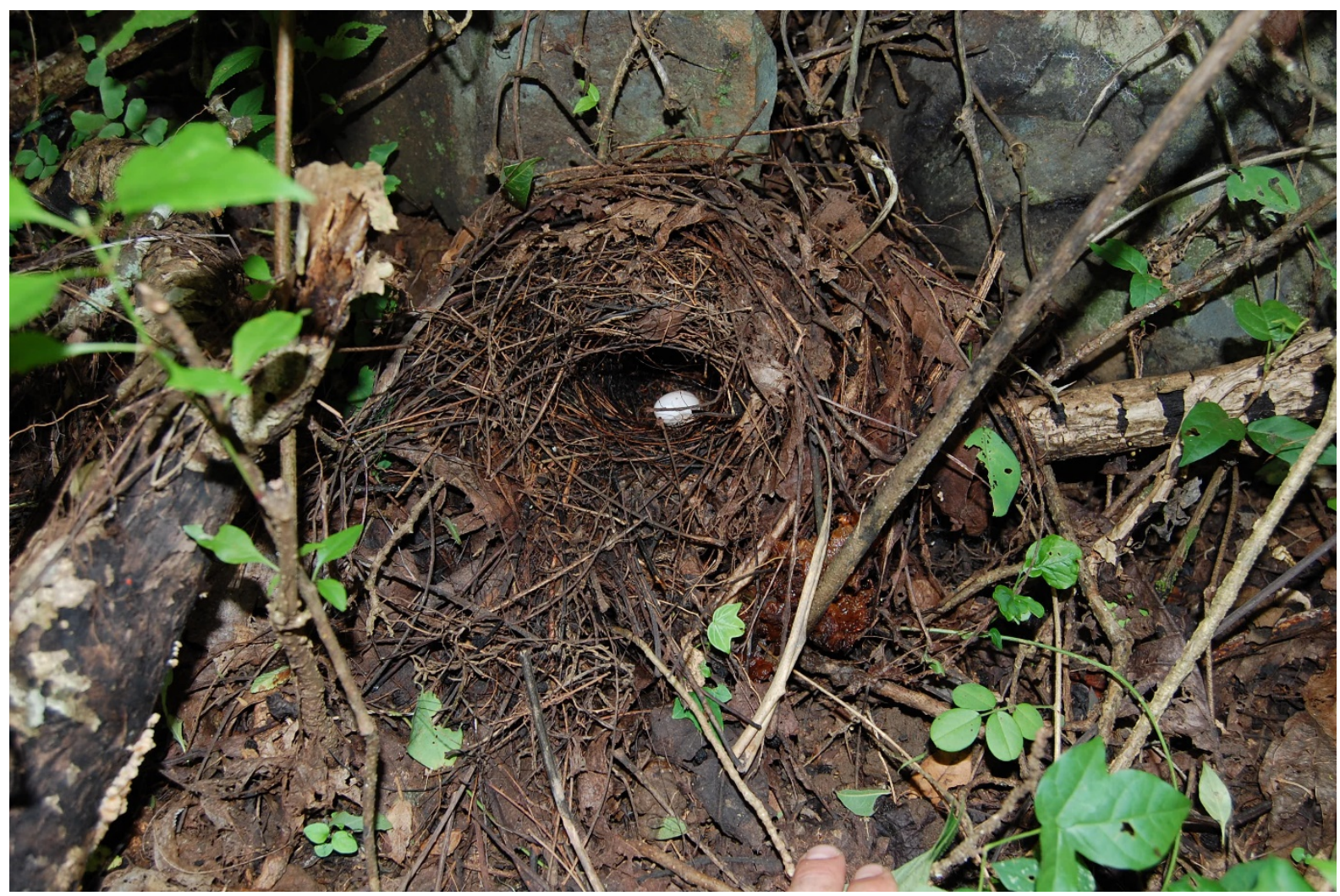

Figure 1: A nest of Black-capped Sparrow Arremon abeillei abeillei with an incomplete clutch of two eggs, 14 February 2010, Jorupe, Ecuador (photo H. F. Greeney).

Table 1. Breeding activity of Black-capped Sparrow Arremon abeillei abeillei in southwestern Ecuador. Stage: B = building; $\mathrm{I}=$ incubation; $\mathrm{N}=$ nestling; $\mathrm{CF}=$ carrying food, nestlings or fledglings; $\mathrm{F}$ = fledgling.

\begin{tabular}{|c|c|c|c|}
\hline Date & Location & Stage & Observations \\
\hline 25 February 2006 & Cerro Blanco & $\mathrm{I}$ & $\begin{array}{l}\text { Four fresh eggs, nest is } 40 \mathrm{~cm} \text { from bottom of } 1.5 \mathrm{~m} \text { tall bank on } \\
\text { edge of small drainage. }\end{array}$ \\
\hline 28 February 2006 & Cerro Blanco & $\mathrm{N}$ & $\begin{array}{l}\text { Four nestlings, nest situated } 1.5 \mathrm{~m} \text { from bottom of } 2.5 \mathrm{~m} \text {-tall } \\
\text { bank on edge of small drainage with no water, } 25 \mathrm{~m} \text { from actual } \\
\text { stream. }\end{array}$ \\
\hline 8 April 2006 & Jorupe & $\mathrm{F}$ & At least one fledgling traveling with adults, but no feeding seen. \\
\hline 12 April 2006 & Jorupe & $\mathrm{F}$ & Pair of adults feeding at least one fledgling. \\
\hline 12 April 2006 & Jorupe & $\mathrm{F}$ & Second pair of adults feeding at least one fledgling. \\
\hline 18 April 2006 & Jorupe & $\mathrm{F}$ & Young fledgling, perched in low vegetation. \\
\hline 23 April 2006 & Jorupe & $\mathrm{CF}$ & Pair of adults carrying food repeatedly to same area. \\
\hline 14 February 2010 & Jorupe & $\mathrm{L}$ & $\begin{array}{l}\text { Two fresh eggs, third egg laid } 15 \text { February, nest partially } \\
\text { destroyed and abandoned on } 16 \text { February. }\end{array}$ \\
\hline 17 February 2010 & Jorupe & $\mathrm{N}$ & Three mid-aged nestlings. \\
\hline 1 March 2010 & Jorupe & I & $\begin{array}{l}\text { Four fresh eggs, three of Black-capped Sparrow, one of Shiny } \\
\text { Cowbird, eggs disappeared on or before } 3 \text { March. }\end{array}$ \\
\hline 1 March 2014 & Jorupe & $\mathrm{B}$ & Just beginning construction. \\
\hline 29 March 2014 & Jorupe & $\mathrm{B}$ & Three eggs laid by 2 March. \\
\hline
\end{tabular}

\section{Nestlings}

A nest at Cerro Blanco contained four young nestlings (Fig. 3) on 28 February 2006. The young nestlings, with eyes still closed, had dusky pink skin. Their legs and bills were slightly duskier than skin and contrasted with their bright yellow-white rictal flanges and deep red mouth linings. They had a moderately dense covering of dark gray natal down. No contour or flight feather pins had broken through the skin. At Jorupe, on 17 February 2010, a nest contained three mid-aged nestlings (Fig. 4), whose primary pin feathers I estimate to have broken 
their sheaths within the past $48 \mathrm{~h}$. The nestlings had tarsal lengths $(\mathrm{mm})$ of $23.8,24.7$, and 24.4 , respectively weighing $17.2 \mathrm{~g}, 18.2 \mathrm{~g}$, and $18.5 \mathrm{~g}$. The adults appeared greatly agitated by my visit to the nest, making sharp chip calls and generally staying 3-5 m away and hidden behind thick vegetation. Only when one of the nestlings vocalized while I handled it, did the adults approached, still chipping, to within 1.5-2 m, one of them performing what appeared to be a brief broken-wing display.
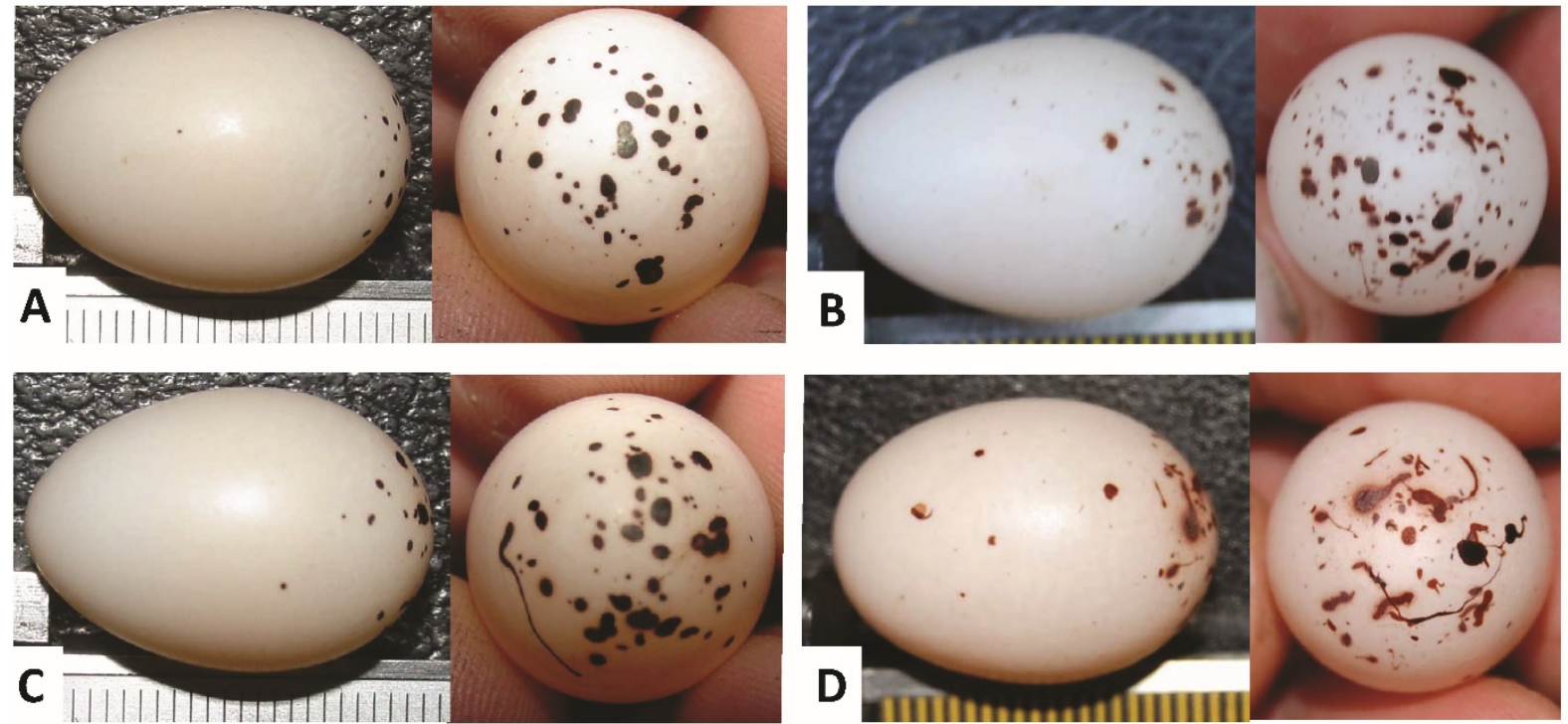

Figure 2: Eggs of Black-capped Sparrow Arremon abeillei abeillei, in southwest Ecuador. A) 25 February 2006, Cerro Blanco; B) 14 February 2010, Jorupe; C) 25 February 2006, Cerro Blanco, same clutch as A; D) 15 February 2010, Jorupe, same clutch as B (photos H. F. Greeney).

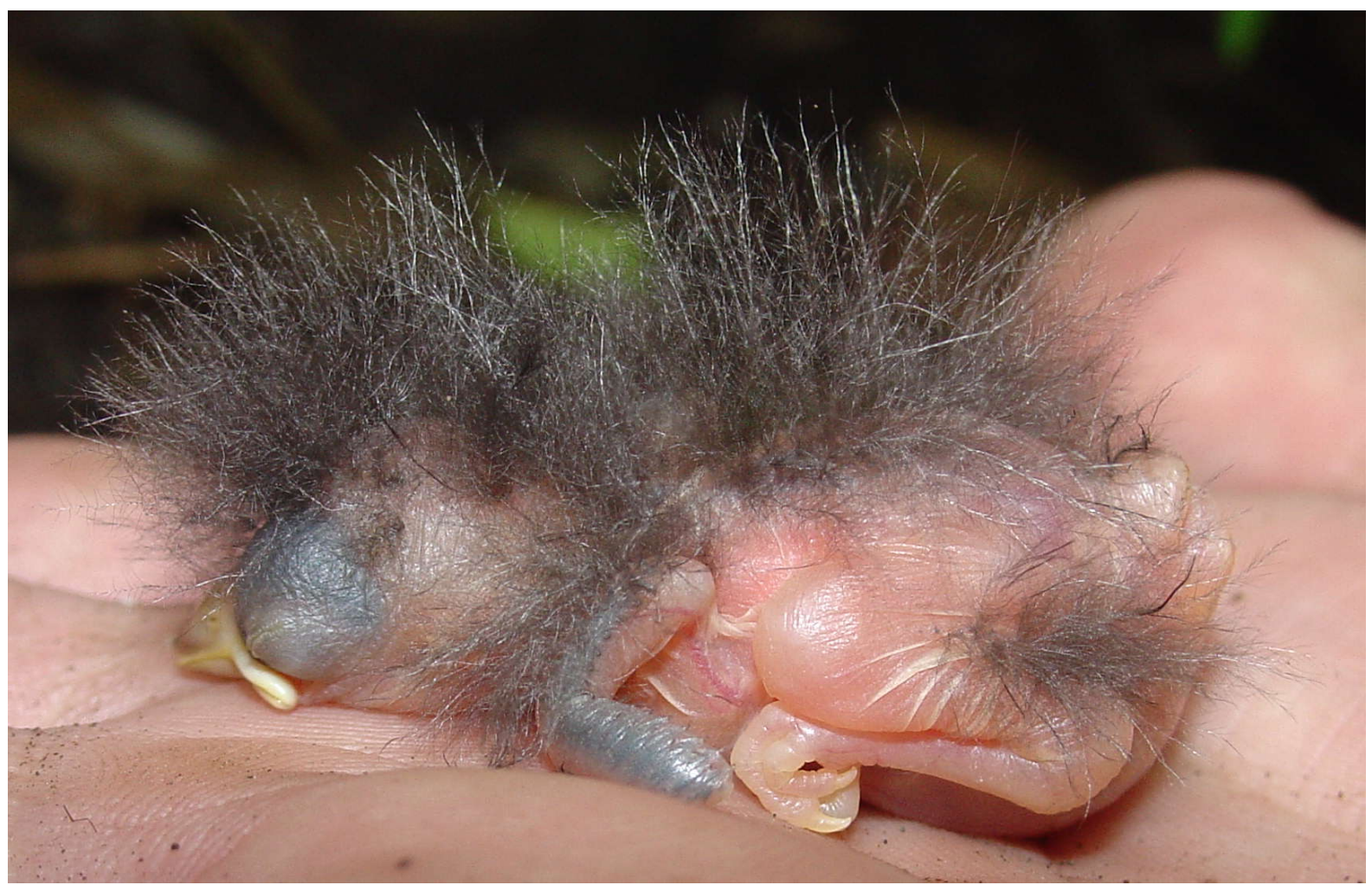

Figure 3: Young nestling of Black-capped Sparrow Arremon abeillei abeillei, 28 February 2006, Cerro Blanco, Ecuador (photo H. F. Greeney). 
Table 2. Linear measurements for six nests of Black-capped Sparrow Arremon abeillei abeillei in southwestern Ecuador. Seven measurements are given $(\mathrm{cm})$ : A) external height; B) external width; C) external depth (front to back); D) opening (entrance) height; E) opening width; F) internal diameter (egg cup and chamber); G) total internal height of nest chamber; H) internal depth (of egg cup).

\begin{tabular}{lrrrrrrrr}
\hline & A & B & C & D & E & F & G & H \\
\hline Nest 1 & 18 & 13 & 13 & 5.5 & 6.5 & 7 & 8.5 & 5 \\
Nest 2 & 15 & 12 & 12 & 5 & 6 & 7 & 9 & 4.5 \\
Nest 3 & 16 & 14 & 13 & 4 & 6.5 & 7 & 8.5 & 5.5 \\
Nest 4 & 16 & 12 & 12 & 5 & 6.5 & 8 & 8.5 & 5.5 \\
Nest 5 & 14 & 14 & 15 & 6 & 7 & 8 & 10 & 4.5 \\
Nest 6 & 15 & 16 & 14 & 5 & 6 & 7.5 & 8 & 5 \\
Mean & 15.7 & 13.5 & 13.2 & 5.1 & 6.4 & 7.4 & 8.8 & 5.0 \\
STDEV & 1.4 & 1.5 & 1.2 & 0.7 & 0.4 & 0.5 & 0.7 & 0.4 \\
\hline
\end{tabular}

\section{DISCUSSION}

This is apparently the first record of brood parasitism for Black-capped Sparrow, and represents a new host record for Shiny Cowbird (Friedmann \& Kiff, 1985; Fraga, 2018). Previous host records include other species of Arremon, as well as both Arremonops and Atlapetes species (Friedmann et al., 1977, 1985). Cowbird parasitism presents a serious threat to at least one relative of Black-capped Sparrow, the Pale-headed Brushfinch Atlapetes pallidiceps (Oppel et al., 2004), also a Tumbesian endemic (Birdlife International 2017). The frequency of brood parasitism in Black-capped Sparrow remains unknown, but its potential as a host and the possible conservation repercussions deserve closer inspection.

Table 3. Nest description of Black-capped Sparrow Arremon abeillei abeillei described in the literature.

\begin{tabular}{|c|c|c|}
\hline English name & Latin name & Source \\
\hline Sooty-faced Finch & Arremon crassirostris & Barrantes, 1994; Young \& Zook, 1999 \\
\hline Olive Finch & Arremon castaneiceps & $\begin{array}{l}\text { Schulenberg \& Gill, 1987; Rasmussen et al., } \\
\text { 1996; Greeney \& Gelis, 2006; Flórez-V. \& } \\
\text { Londoño, } 2012\end{array}$ \\
\hline \multirow{5}{*}{$\begin{array}{l}\text { Chestnut-capped Brush- } \\
\text { finch }\end{array}$} & Arremon brunneinucha suttoni & Rowley, 1966, 1984 \\
\hline & Arremon b. macrourus & Baepler, 1962; Skutch, 1967 \\
\hline & Arremon b. apertus & Edwards \& Tashain, 1959 \\
\hline & Arremon b.elsae & Carriker, 1910; Skutch, 1967 \\
\hline & Arremon $b$. frontalis & Taczanowski, 1884 \\
\hline $\begin{array}{l}\text { Green-striped Brush- } \\
\text { finch }\end{array}$ & Arremon virenticeps & Rowley, 1962 \\
\hline Costa Rican Brush-finch & Arremon costaricensis & Skutch, 1954 \\
\hline $\begin{array}{l}\text { White-browed Brush- } \\
\text { finch }\end{array}$ & Arremon torquatus borellii & Auer et al., 2007 \\
\hline \multirow[t]{2}{*}{ Saffron-billed Sparrow } & Arremon flavirostris dorbignii & $\begin{array}{l}\text { di Giacomo \& López-Lanús, 1998; de la } \\
\text { Peña, } 2005\end{array}$ \\
\hline & Arremon f.polionotus & $\begin{array}{l}\text { Hartert \& Venturi, 1909; Dinelli, 1918; di } \\
\text { Giacomo, } 2005\end{array}$ \\
\hline \multirow[t]{2}{*}{ Pectoral Sparrow } & Arremon taciturnus taciturnus & Haverschmidt, 1962 \\
\hline & Arremon t. nigrirostris & Valdez-Juárez \& Londoño, 2011 \\
\hline Half-collared Sparrow & Arremon semitorquatus & Euler, 1900 \\
\hline \multirow[t]{3}{*}{ Orange-billed Sparrow } & $\begin{array}{l}\text { Arremon aurantiirostris } \\
\text { rufidorsalis }\end{array}$ & Richmond, 1893 \\
\hline & A. a. aurantiirostris & Skutch, 1954 \\
\hline & A. a. saturata & del Toro, 1952 \\
\hline Golden-winged Sparrow & Arremon schlegeli schlegeli & Tye \& Tye, 1992 \\
\hline
\end{tabular}


Following the taxonomic arrangement of del Hoyo et al. (2018), there are now adequate nest and egg descriptions available for 20 taxa of Arremon sparrows (Table 3). These descriptions provide a clear division into two groups within Arremon, as it is currently defined (del Hoyo et al., 2018; Remsen et al., 2018). The first group (hereafter Nest Group 1) includes taxa which lay unmarked white or pale bluish eggs and build broad, open-cup nests: A. brunneinucha suttoni, A. b. macrourus, A. b. apertus, A. b. elsae, A. $b$. frontalis, $A$. virenticeps, $A$. costaricensis, and A. torquatus borellii. The second group (hereafter Nest Group 2) lays white or pale buffy eggs with sparse dark spotting and build enclosed, oven-shaped nests with a lateral entrance: $A$. flavirostris dorbignii, A. f. polionotus, A. taciturnus taciturnus, A. t. nigrirostris, A. semitorquatus, A. aurantiirostris rufidorsalis, A. a. aurantiirostris, A. a. saturata and A. s. schlegeli). The two similar taxa historically included in the genus Lysurus (A. crassirostris and A. castaneiceps; see Ridgely \& Tudor, 2009) do not fit neatly into either of these nest groups (see below).

The taxonomic history of species in Nest Group 1 is complex and, at times, all taxa have been lumped into two (Wetmore et al., 1984; Fjeldså \& Krabbe, 1990) or three (Ridgely \& Tudor, 1989, 2009) species. Prior to recent phylogenetic analyses (Cadena et al., 2007; Klicka et al., 2014), members of Nest Group 1 have been placed either in Buarremon or Atlapetes (Hellmayr, 1938; Paynter, 1970; Ridgely \& Greenfield, 2001; Dickinson 2003); see Remsen \& Graves (1995a, 1995b) and Cadena \& Cuervo (2010) for further details. So far as is known, members of the genus Atlapetes build open-cup nests and lay white eggs with cinnamon or vinaceous spotting (Rowley, 1962, 1966; Salaman et al., 1998; Oppel et al., 2003; de la Peña, 2005; Biancucci \& Martin, 2008; Greeney, 2009; Peraza, 2009; Olaciregui \& Botero-Delgadillo, 2012; Forrester \& Londoño, 2016). Sparrows in the closely related genus Arremonops (del Hoyo et al., 2018), sometimes merged into Arremon (Phelps \& Phelps, 1950; Meyer de Schauensee, 1951) lay unmarked eggs like Nest Group 1, but clearly have nest architecture that is nearly indistinguishable from members of Nest Group 2 (Merrill, 1878; Sennett, 1878; Stone, 1918; Skutch, 1954; Rowley, 1984; Salgado-Ortiz et al., 2001). As mentioned above, A. crassirostris and A. castaneiceps, previously separated in the genus Lysurus fall most readily within Nest Group 2, particularly with respect to nest architecture. The eggs of both species, however, are in fact most similar to eggs of the genus Atlapetes, being marked with cinnamon or vinaceous spotting rather than the darker and sparser markings of Nest Group 2. It is interesting to note that eggs of A. castaneiceps described from numerous clutches from several portions of its range, vary in coloration, both within and between populations, from well-marked with cinnamon spotting to completely unmarked (Sclater \& Salvin, 1879; Schulenberg \& Gill, 1987; Rasmussen et al., 1996; Greeney \& Gelis, 2006; Flórez-V. \& Londoño, 2012). In conclusion, it is clear that further natural history data and additional molecular analyses are needed to completely understand the complex relationships within the currently-defined group of sparrows in the genera Atlapetes, Arremonops and Arremon.

\section{ACKNOWLEDGEMENTS}

My field work, and the purchase of equipment used in this study, were supported by Matt Kaplan, John V. Moore, the Population Biology Foundation, and Field Guides, Inc. During the writing process, I was supported by a John Simon Guggenheim Memorial Fellowship and inspired by the PBNHS. I would like to thank Pancho Sornoza and the Jocotoco Foundation for facilitating access to the Foundation's reserve. Luis A. Salagaje M., Rudy A. Gelis, Eliot T. Miller, Leonidas F. Cabrera, Isaac Lichter-Marck, and Eli Lichter-Marck all helped with field work and contributed unpublished observations and data. I thank Kristof Zyskowski for discussions and help with literature.

\section{REFERENCES}

Armani, G. C. (1985). Guide des passereaux granivores: embérizinés. Paris, France: Société Nouvelle des Editions Boubée.

Auer, S. K., Bassar, R. D., Fontaine, J. J., \& Martin, T. E. (2007). Breeding biology of passerines in a subtropical montane forest in northwestern Argentina. Condor, 109, 321-333. https://doi.org/10.1650/00105422(2007)109[321:bbopia]2.0.co;2

Baepler, D. H. (1962). The avifauna of the Soloma region in Huehuetenango, Guatemala. Condor, 64, 140-153. https://sora.unm.edu/sites/default/files/journals/condor/v064n02/p0140-p0153.pdf 
Barrantes, G. (1994). First description of the nest and eggs of the Sooty-faced Finch. Wilson Bulletin, 106, 574 https://sora.unm.edu/sites/default/files/journals/wilson/v106n03/p0574-p0574.pdf

Best, B. J., \& Clarke, C. T. (1991). The Threatened birds of the Sozoranga Region, southwest Ecuador. Cambridge, UK: International Council for Bird Preservation.

Best, B. J., \& Kessler, M. (1995). Biodiversity and conservation in Tumbesian Ecuador and Peru. Cambridge, U. K.: BirdLife International.

Biancucci, L., \& Martin, T.E. (2008). First description of the breeding biology and natural history of the Ochrebreasted Brush Finch (Atlapetes semirufus). Wilson Journal of Ornithology, 120, 856-862. https://doi.org/10.1676/07-020.1

BirdLife International (2017, November 3) Endemic Bird Areas factsheet: Tumbesian region. URL: http://datazone.birdlife.org/eba/factsheet/47.

Cadena, C. D., \& Cuervo, A. M. (2010). Molecules, morphology, ecology, and songs in concert: How many species is "Arremon torquatus" (Aves, Emberizidae)? Biological Journal of the Linnean Society, 99, 152-176. https://doi.org/10.1111/j.1095-8312.2009.01333.x

Cadena, C. D., Klicka, J., \& Ricklefs, R. E. (2007). Evolutionary differentiation in the Neotropical montane region: Molecular phylogenetics and phylogeography of Buarremon brush-finches (Aves, Emberizidae). Molecular Phylogenetics and Evolution, 44, 993-1016. https://doi.org/10.1016/j.ympev.2006.12.012

Carriker, M. A., Jr. (1910). An annotated list of the birds of Costa Rica, including Cocos Island. Annals of the Carnegie Museum, 6, 314-915.

Curson, J. M. (2010). Family Parulidae (New World Warblers). In J. del Hoyo, A. Elliott \& D. A. Christie (Eds.), Handbook of the birds of the world, volume 15: weavers to New World warblers (pp. 666-802). Barcelona, Spain: Lynx Edicions.

Dickinson, E. C. (2003). The Howard \& Moore complete checklist of the birds of the world. Revised and enlarged 3rd Edition. London: Christopher Helm.

Dickinson, E. C., \& Christidis, L. (Eds.). (2014). The Howard and Moore complete checklist of the birds of the world. 4th Edition. Volume 2, Passerines. Eastbourne, United Kingdom: Aves Press.

Dinelli, L. (1918). Notas biológicas sobre aves del noroeste de la república de Argentina. Hornero, 1(2), 57 68. http://digital.bl.fcen.uba.ar/Download/008_ElHornero/008_ElHornero_v001_n02_articulo057.pdf

Edwards, E. P., \& Tashian, R. E. (1959). Avifauna of the Catemaco Basin of southern Veracruz, Mexico. Condor, 61, 325-337. https://sora.unm.edu/node/101133

Euler, C. (1900). Descripção de ninhos e ovos das aves do Brasil. Revista do Museu Paulista, 4, 9-148.

Fjeldså, J., \& Krabbe, N. (1990). The birds of the high Andes. Svendborg, Denmark: Copenhagen \& Apollo Books.

Flórez-V., C., \& Londoño, G. A. (2012). Biología de anidación del Pinzón Oliva (Arremon castaneiceps) en el sureste peruano. Ornitología Neotropical, 23, 417-427. https://sora.unm.edu/node/133326

Forrester, T. R., \& Londoño, G. A. (2016). Breeding biology and egg temperatures of Black-faced Brush-finches (Atlapetes melanolaemus), Neotropical montane songbird. Journal of Field Ornithology, 87(3), 260-272. https://doi.org/10.1111/jofo.12155 
Fraga, R. (2018, February 23). Shiny Cowbird (Molothrus bonariensis). In J. del Hoyo, A. Elliott, J. Sargatal, D. A. Christie \& E. de Juana (Eds.), Handbook of the birds of the world alive. Barcelona, Spain: Lynx Edicions. URL: https://www.hbw.com/node/62296.

Friedmann, H., \& Kiff, L. F. (1985). The parasitic cowbirds and their hosts. Proceedings of the Western Foundation of Vertebrate Zoology, 2, 225-304.

Friedmann, H., Kiff, L. F., \& Rothstein, S. I. (1977). A further contribution to knowledge of the host relations of the parasitic cowbirds. Smithsonian Contributions to Zoology, 235, 1-75.

di Giacomo, A. G. (2005). Aves de la Reserva El Bagual. In A. G. Di Giacomo \& S. Krapovickas (Eds.), Historia natural y paisaje de la Reserva El Bagual, provincia de Formosa, Argentina. Inventario de la fauna de vertebrados y de la flora vascular de un área protegida del Chaco Húmedo (pp. 201-465). Buenos Aires, Argentina: Aves Argentinas/AOP.

di Giacomo, A. G., \& López-Lanús, B. (1998). Aportes sobre la nidificación de veinte especies de aves del noroeste argentino. Hornero, 15, 29-38.

Greeney, H. F. (2009). The nest, eggs, and nestlings of the Rufous-naped Brush-Finch (Atlapetes latinchus latinuchus) in southeastern Ecuador. Ornitología Colombiana, 8, 83-87.

Greeney, H. F., \& Gelis, R. A. (2006). Observations on the nesting of the Olive Finch (Lysurus castaneiceps) in eastern Ecuador. Ornitología Neotropical, 17, 147-149. https://sora.unm.edu/node/119746

Hartert, E., \& Venturi, S. (1909). Notes sur les oiseaux de la Republique Argentine. Novitates Zoologicae, 16(2), $159-267$.

Haverschmidt, F. (1962). Notes on some Suriname breeding birds (II). Ardea, 50, 173-179.

Hellmayr, C. E. (1938). Catalogue of birds of the Americas. Part 11, Ploceidae, Catamblyrhynchidae, Fringillidae. Field Museum of Natural History (Zoological Series), 13, 1-662.

del Hoyo, J., \& Collar, N. J. (2016). HBW and BirdLife International illustrated checklist of birds of the world, vol. 2: Passerines. Barcelona, Spain: Lynx Edicions.

del Hoyo, J., Elliott, A., Sargatal, J., Christie, D. A., \& de Juana, E. (Eds.) (2018, February 23). Handbook of the birds of the world alive. Barcelona, Spain: Lynx Edicions. https://www.hbw.com.

Jaramillo, A. (2018, February 23). Black-capped Sparrow (Arremon abeillei). In J. del Hoyo, A. Elliott, J. Sargatal, D. A. Christie \& E. de Juana (Eds.), Handbook of the Birds of the World alive. Barcelona, Spain: Lynx Edicions. URL: https://www.hbw.com/node/61964.

Klicka, J., Barker, F. K., Burns, K. J., Lanyon, S. M., Lovette, I. J., Chaves, J. A., \& Bryson, R. W. (2014). A comprehensive multilocus assessment of sparrow (Aves: Passerellidae) relationships. Molecular Phylogenetics and Evolution, 77, 177-182. https://doi.org/10.1016/j.ympev.2014.04.025

Merrill, J. C. (1878). On the ornithology of southern Texas being a list of birds observed in the vicinity of Fort Brown, Texas from February 1876 to June 1878. Proceedings of the United States National Museum, 1, 118 175.

Meyer de Schauensee, R. M. (1951). The birds of the Republic of Colombia. Caldasia, 5(25), 873-1112.

Miller, E. T., Greeney, H. F., Lichter-Marck, I., Lichter-Marck, E., \& Cabrera, L. F. (2012). The breeding of the Henna-hooded Foliage-gleaner, Hylocryptus erythrocephalus, with notes on conservation concerns. Ornitología Neotropical, 23, 517-527. https://sora.unm.edu/sites/default/files/ON\%2023\%284\%29\%20517527.pdf 
Mischler, T. C. (2012). Status, abundance, seasonality, breeding evidence and an updated list of the birds of Cerro Blanco, Guayaquil, Ecuador. Cotinga, 34, 60-72. https://www.neotropicalbirdclub.org/wpcontent/uploads/2018/06/C34-Mischler.pdf

Mischler, T. C., \& Sheets, D. R. (2007). Catálogo diagnóstico de las aves del Bosque Protector Cerro Blanco. Guayaquil, Ecuador: BirdLife International, Fundación Pro-Bosque y Universidad Católica de Santiago de Guayaquil.

Olaciregui, C. A., \& Botero-Delgadillo, E. (2012). The nest and eggs of the Santa Marta Brush-finch (Atlapetes melanocephalus) with notes on its reproductive biology. Ornitología Colombiana, 12, 25-31.

Oppel, S., Schaefer, H. M., \& Schmidt, V. (2003). Description of the nest, eggs, and breeding behavior of the endangered Pale-headed Brush-Finch (Atlapetes pallidiceps) in Ecuador. Wilson Bulletin, 115, 360-366. https://doi.org/10.1676/03-020

Oppel, S., Schaefer, H. M., Schmidt, V., \& Schroder, B. (2004). Cowbird parasitism of Pale-headed Brushfinch Atlapetes pallidiceps: implications for conservation and management. Bird Conservation International, 14, 63-75. https://doi.org/10.1017/S0959270904000103

Paynter, R. A., Jr. (Ed.). (1970). Check-list of birds of the World, Volume 13. Cambridge, Massachusetts, U.S.A.: Museum of Comparative Zoology, Harvard. https://doi.org/10.5962/bhl.title.14581

de la Peña, M. R. (2005). Reproducción de las aves argentinas (con descripción de pichones). Buenos Aires, Argentina: Literature of Latin America.

Peraza, C. A. (2009). First record of nest and eggs of the Pale-naped Brush-finch (Atlapetes pallidinucha). Wilson Journal of Ornithology, 121, 159-163. https://www.jstor.org/stable/20616868

Phelps, W. H., \& Phelps, W. H., Jr. (1950). Lista de las aves de Venezuela con su distribución. Tomo I, Parte II. Passeriformes, primera edición. Boletín de la Sociedad Venezolana de Ciencias Naturales, 12, 1-427.

Rasmussen, J. F., Rahbek, C., Poulsen, B. O., Poulsen, M. K., \& Bloch, H. (1996). Distributional records and natural history notes on threatened and little-known birds of southern Ecuador. Bulletin of the British Ornithologists' Club, 116, 26-45.

Remsen, J. V., Jr., \& Graves, W. S. (1995a). Distribution patterns and zoogeography of Atlapetes brush-finches (Emberizinae) of the Andes. Auk, 112, 210-224. https://doi.org/10.2307/4088780

Remsen, J. V., Jr., \& Graves, W. S. (1995b). Distribution patterns of Buarremon brush-finches (Emberizinae) and interspecific competition in Andean birds. Auk, 112, 225-236. https://doi.org/10.2307/4088781

Remsen, J. V., Jr., Areta, J. I., Cadena, C. D., Claramunt, S., Jaramillo, A., Pacheco, J. F., Pérez-Emán, J., Robbins, M. B., Stiles, F. G., Stotz, D. F., \& Zimmer, K. J. (2018, February 23). A classification of the bird species of South America. Washington, D. C., U.S.A.: American Ornithologists' Union. http://www.museum.lsu.edu/ Remsen/SACCBaseline.htm

Richmond, C. W. (1893). Notes on a collection of birds form eastern Nicaragua and the Río Frío, Costa Rica, with a description of a supposed new trogon. Proceedings of the United States National Museum, 16, 479-532.

Ridgely, R. S., \& Greenfield, P. J. (2001). Birds of Ecuador. Volume 1: Status, distribution, and taxonomy. Ithaca, New York, U.S.A.: Cornell University Press.

Ridgely, R. S., \& Tudor, G. (1989). The birds of South America. Volume 1: The oscine passerines. Oxford, United Kingdom: Oxford University Press.

Ridgely, R. S., \& Tudor, G. (2009). Field guide to the songbirds of South America: Passerines. Austin, TX, U.S.A.: University of Texas Press. 
Rowley, J. S. (1962). Nesting of the birds of Morelos, Mexico. Condor, 24, 253-271. https://doi.org/10.2307/1365365

Rowley, J. S. (1966). Breeding records of birds of the Sierra Madre del Sur, Oaxaca, Mexico. Proceedings of the Western Foundation of Vertebrate Zoology, 1, 107-204.

Rowley, J. S. (1984). Breeding records of land birds in Oaxaca, Mexico. Proceedings of the Western Foundation of Vertebrate Zoology, 2, 73-224.

Salaman, P. G. W., Dávalos, L., \& Kirwan, G. M. (1998). The first breeding records of White-rimmed Brushfinch Atlapetes leucopis with ecological notes. Cotinga, 9, 24-26.

Salgado-Ortiz, J., Figueroa-Esquivel, E. M., Larios-Guzmán, S., \& Robertson, R. J. (2001). Descriptions of nests and eggs of the Green-backed Sparrow and the Grey-throated Chat from the Yucatán Peninsula, México. Wilson Bulletin, 113, 328-331. https://www.jstor.org/stable/4164364

Schulenberg, T. S., \& Gill, F. B. (1987). First description of the nest of the Olive Finch, Lysurus castaneiceps. Condor, 89, 673-674. https://doi.org/10.2307/1368661

Schulenberg, T. S., \& Jaramillo, A. (2013). Black-capped Sparrow (Arremon abeillei) version 1.0. In T. S. Schulenberg (Ed.), Neotropical Birds Online. Ithaca, New York, U.S.A.: Cornell Lab of Ornithology. https://doi.org/10.2173/nb.blcspa2.01

Sclater, P. L. \& Salvin, O. (1879). On the birds collected by the late Mr. T. K. Salmon in the State of Antioquia, United States of Colombia. Proceedings of the Zoological Society of London, 1879, 486-550. https://doi.org/10.1111/j.1096-3642.1879.tb02684.x

Sennett, G. B. (1878). Notes on the ornithology of the lower Rio Grande of Texas, from observations made during the season of 1877. Bulletin of the United States Geological and Geographical Survey of the Territories, $4,1-66$.

Skutch, A. F. (1954). Life histories of Central American birds. Pacific Coast Avifauna No. 31. https://sora.unm.edu/sites/default/files/journals/pca/pca_031.pdf

Skutch, A. F. (1967). Life histories of Central American birds. Cambridge, Massachusetts, U.S.A.: Nuttall Ornithological Club.

Stone, W. (1918). Birds of the Panama Canal Zone with special reference to a collection made by Lindsey L. Jewel. Proceedings of the Academy of Natural Sciences of Philadelphia, 70, 239-280.

Taczanowski, L. (1884). Ornithologie du Pérou (Vol. 2). Berlin, Germany: R. Friedländer \& Sohn. https://www.archive.org/download/ornithologiedup02tacz/ornithologiedup02tacz.pdf

Todd, W. E. C. (1923). A synopsis of the genus Arremonops. Proceedings of the Biological Society of Washington, 36, 35-44. https://www.biodiversitylibrary.org/bibliography/3622\#/summary

del Toro, M. A. (1952). Contribución al conocimiento de la oología y nidología de las aves chiapenecas. Ateneo de Ciencias y Artes de Chiapas, 4, 11-21.

Tye, H., \& Tye, A. (1992). First description of the eggs and nest of the Golden-winged Sparrow Arremon schlegeli. Ornitología Neotropical, 3, 71.

Valdez-Juárez, S. O., \& Londoño, G. A. (2011). Nesting of the Pectoral Sparrow (Arremon taciturnus) in southeastern Peru. Wilson Journal of Ornithology, 123, 808-813. https://www.jstor.org/stable/41480551

Wetmore, A., Pasquier, R. F., \& Olson, S. L. (1984). Birds of the Republic of Panama. Part IV Passeriformes: Hirundinidae (Swallows) to Fringillidae (Finches). Washington, D.C., U.S.A.: Smithsonian Institution Press. 
https://www.archive.org/download/birdsofrepublico04wetm/birdsofrepublico04wetm.pdf

Young, B. E., \& Zook, J. R. (1999). Nesting of four poorly-known bird species on the Caribbean slope of Costa Rica. Wilson Bulletin, 111, 124-128. https://sora.unm.edu/node/131645

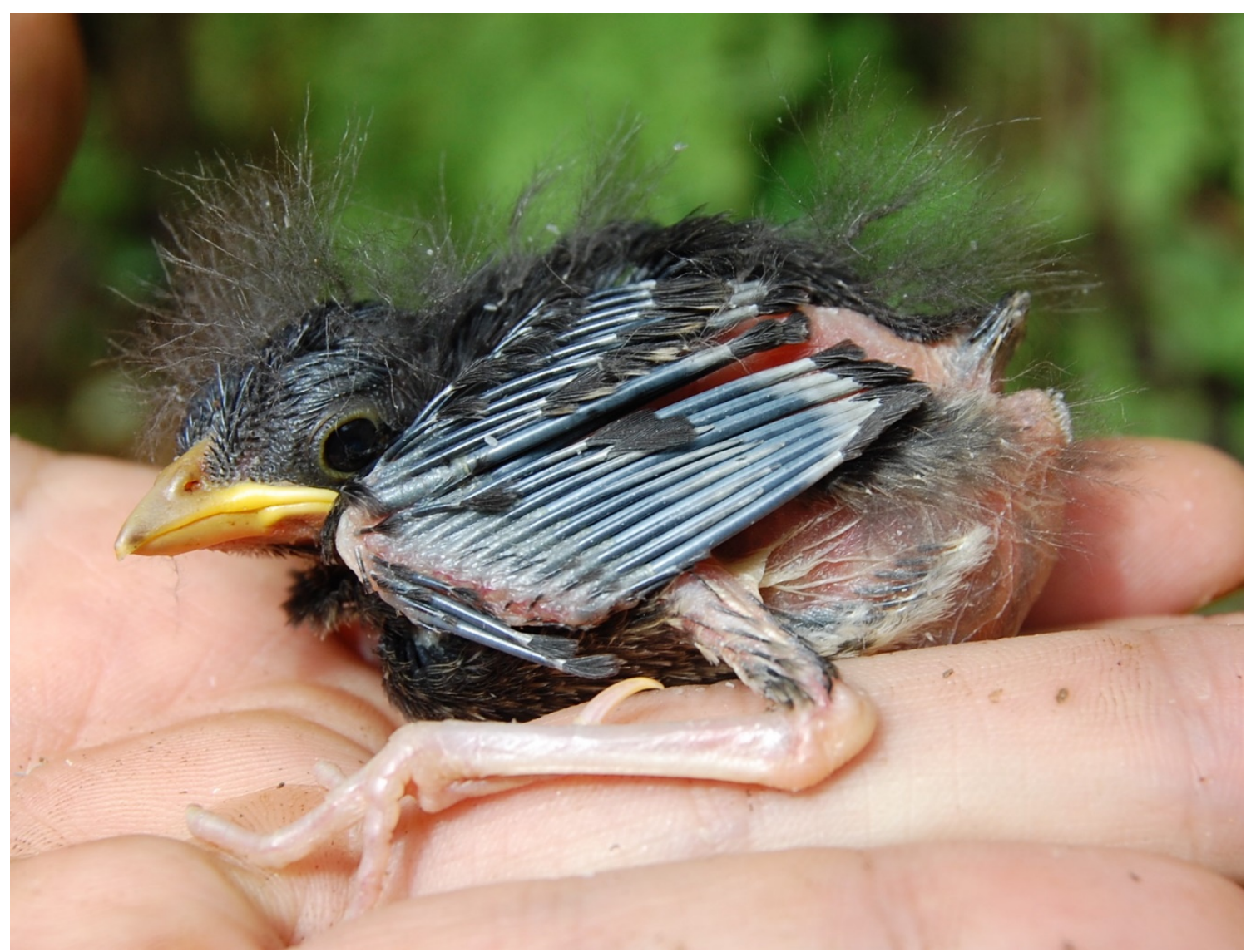

Figure 4: Mid-aged nestling of Black-capped Sparrow Arremon abeillei abeillei, 17 February 2010, Jorupe, Ecuador (photo H. F. Greeney). 